\author{
ADRIAN ULJASZ \\ Uniwersytet Rzeszowski \\ (D) https://orcid.org/0000-0003-3831-4585
}

\title{
DOKUMENTY ŻYCIA SPOŁECZNEGO Z KOLEKCJI KSIĘGARZA MARIANA KRZYŻANOWSKIEGO JAKO ŹRÓDŁO DO BADAŃ NAD ŻYCIEM MUZYCZNYM ORAZ TEATRALNYM KRAKOWA I WARSZAWY W XIX I XX WIEKU
}

Słowa kluczowe: Marian Krzyżanowski (1880-1964); życie muzyczne, teatr, Kraków, Warszawa, XIX w., XX w., historia

Cenne źródło w badaniach nad tradycją życia teatralnego i muzycznego konkretnych miast stanowią programy i afisze realizacji teatralnych oraz koncertów, a także podobne druki. W zbiorach Biblioteki Naukowej PAU i PAN w Krakowie znajdują się materiały tego rodzaju odnoszące się do wydarzeń kulturalnych mających miejsce w Krakowie i Warszawie, zgromadzone przez krakowskiego księgarza, antykwariusza i wydawcę Mariana Krzyżanowskiego. Są to afisze koncertów muzyki klasycznej, programy teatralne i zaproszenia. Daty krańcowe powstania dokumentów to lata $1884-1955^{1}$. Zbiór trafił do biblioteki w 1956 r. jako zakup od właściciela².

Marian Krzyżanowski (1880-1964) był synem księgarza, wydawcy i nakładcy z Krakowa Stanisława Andrzeja Krzyżanowskiego (1836-1922). Jego ojciec prowadził księgarnię od 1870 r., z początku na Floriańskiej, pod numerem $7^{3}$.

1 Zob. Biblioteka Naukowa PAU i PAN w Krakowie (dalej: BN PAU i PAN), rkps 3736. Drukowane programy koncertowe i teatralne z papierów Mariana Krzyżanowskiego, k. 1-22 (całość kolekcji). Zob. też Katalog rękopisów Biblioteki Polskiej Akademii Nauk w Krakowie. Sygnatury 3607-4003, oprac. B. Schnaydrowa, J. Staszel, pod red. Z. Jabłońskiego, Wrocław 1976, s. 52-53 (spis kolekcji zgromadzonej pod powyższą sygnaturą).

2 Katalog rękopisów..., s. 53.

3 F. Pie czątkowski, Krzyżanowski Stanisław Andrzej (15 II 1836 - 11 X 1922 Kraków), księgarz, naktadca, w: Słownik pracowników książki polskiej, pod red. I. Treichel, Warszawa-Łódź 1972, s. 479; idem, Krzyżanowski Marian (26 IV 1880 Kraków - 7 IX 1964 tamże) księgarz, naktadca $i$ antykwariusz, w: ibidem, s. 479; B. Ło pu szań s k i, Krzyżanowski Stanisław Andrzej Błażej (1836-1922). Księgarz i wydawca, w: Polski stownik biograficzny (dalej: PSB), t. 15, WrocławWarszawa-Kraków 1970, s. 617; F. P i e c zą tk ow ski, Krzyżanowski Marian (1880-1964), księgarz, wydawca i antykwariusz, w: PSB, t. 15, s. 612; A. Ruta, Księgarnia „, S.A. Krzyżanowski” 
W notatce wydrukowanej w numerze 169 „Kuriera Warszawskiego” z tego roku informowano: „W Krakowie otworzoną została księgarnia pana Krzyżanowskiego przy ulicy Floriańskiej”" . Po pięciu latach firma zmieniła lokalizację, przenosząc się na Rynek Główny 36, do kamienicy na rogu Rynku i ul. Sławkowskiej5.

Stanisław Krzyżanowski oprócz książek i czasopism wydawał oraz sprzedawał na dużą skalę druki muzyczne - nuty. Firma Krzyżanowskiego należała do najważniejszych polskich księgarń muzycznych. Właściciel prowadził przy sklepie wypożyczalnię materiałów nutowych. Był animatorem życia muzycznego w Krakowie, organizując koncerty ojczystych i zagranicznych muzyków w ramach działalności biura koncertowego funkcjonującego przy księgarni od początku jej istnienia, czyli od 1870 r. Występy odbywały się w sali koncertowej miejscowego Hotelu Saskiego, a sprzedaż biletów prowadzono w księgarni Krzyżanowskiego. To dzięki niemu w 1879 r. w Krakowie odbył się pierwszy koncert kompozytora oraz pianisty wirtuoza Ignacego Jana Paderewskiego, mającego wówczas dziewiętnaście lat. Krzyżanowski z powodzeniem urządzał także występy innych międzynarodowych sław, takich jak rosyjski kompozytor, pianista, a także dyrygent Anton Rubinstein, skrzypkowie i kompozytorzy Eugène Ysaÿe i Pablo Sarasate, kompozytor Johannes Brahms czy gwiazda Metropolitan Opera, śpiewaczka Marcelina Sembrich-Kochańska ${ }^{6}$. Właściciel biura koncertowego organizował i promował występy słynnych wirtuozów, a także brał na firmę ryzyko koncertów przyszłych legend sztuki muzycznej ${ }^{7}$. Koncerty nie dawały mu dochodu, ale doskonale służyły promocji księgarni ${ }^{8}$.

Krzyżanowski jako wydawca edytował polskie książki oraz nuty utworów polskich kompozytorów, m.in. Jana Galla, Zygmunta Noskowskiego, Adama Wrońskiego i Władysława Żeleńskiego. Księgarnia na Rynku Głównym była miejscem spotkań środowiska muzycznego. Noskowski skomponował tam, u swego wydawcy, krakowiaka Skowroneczek śpiewa, czyli najbardziej znaną spośród pieśni

w Krakowie. Zarys dziejów 1870-1950, Kraków 2003, s. 9; J. O k o p i eń, Międzywojenni wydawcy „S.A. Krzyżanowski”, „Wydawca” 1996, nr 11/12, s. 38; J. Zi elińs ki, Wczoraj i dziś S.A. Krzyżanowski, „Gazeta Antykwaryczna” 1998, nr 7-8, s. 11.

4 [Notatka bez tytułu], ,Kurier Warszawski” 1870, nr 169, s. 4.

5 F. Pieczątkowski, Krzyżanowski Stanisław Andrzej..., s. 479; B. Łopuszański, op. cit., s. 617; A. Ruta, op. cit., s. 10-11, [41].

${ }_{6}$ F. Pieczątkowski, Krzyżanowski Stanisław Andrzej..., s. 479; B. Łopuszański, op. cit., s. 617-618; J. Reis s, Almanach muzyczny Krakowa 1780-1914, t. II, Kraków 1939, s. 73; A. Ruta, op. cit., s. [22]-38 (o biurze koncertowym, działającym przy firmie S.A. Krzyżanowskiego - na s. 37-38); J. Okopień, op. cit., s. 38; J. Zieliński, op. cit., s. 11; Z.S. [Z. Stęszewska], Krzyżanowski Stanisław Andrzej, księgarz, właściciel muzycznej firmy wydawniczej w Krakowie, w: Słownik muzyków polskich, t. I, red. nacz. J. Chomiński, Kraków 1964, s. 306-307; M. Krzyża now ski, Wspomnienia księgarza, w: Kopiec wspomnień, oprac. W. Bodnicki, Kraków 1964, s. 138.

7 J. Re is s, Almanach muzyczny Krakowa 1780-1914, t. I, Kraków 1939, s. 155.

8 A. Ruta,op. cit., s. 38. 
stworzonych przez tego kompozytora9 ${ }^{9}$ Jak widać, muzykolog Józef Reiss trafnie zaliczył organizatora występów oraz wydawcę i sprzedawcę nut, Stanisława Krzyżanowskiego, do „krakowskich pionierów muzycznej kultury”"10. Edytor utworów muzycznych korespondował z twórcami, których twórczość promował ${ }^{11}$. Ogłaszał w celach promocyjnych drukowane katalogi swych wydawnictw, książkowych i nutowych, a także wypożyczanych przez siebie nut ${ }^{12}$. Wielu klientów zapewniała także sprzedaż podręczników szkolnych ${ }^{13}$. Książki z jego oferty trafiały do bibliotek, w tym naukowych i gimnazjalnych ${ }^{14}$. W asortymencie księgarni nie brakowało czasopism polskich oraz obcojęzycznych, sprzedawanych m.in. $\mathrm{w}$ formie prenumeraty ${ }^{15}$. Właściciel brał w komis wydawnictwa $\mathrm{z}$ innych księgarń, np. z warszawskiej firmy wydawniczo-księgarskiej Gebethner i Wolff ${ }^{16}$.

9 F. Pieczątkowski, Krzyżanowski Stanisław Andrzej..., s. 479; B. Ło puszański, op. cit., s. 617-618; J. R e is s, op. cit., t. I, Kraków 1939, s. 100, 154-155; Z. J a c hi m e c ki, Muzyka polska od r. 1864 do 1914, w: Polska, jej dzieje i kultura od czasów najdawniejszych do chwili obecnej, t. III, Od roku 1796-1830, w oprac. A. Brücknera et al., s. 896 (rozdział XII); W. Późniak, Pieśń solowa po Moniuszce, w: Z dziejów polskiej kultury muzycznej, t. II Od Oświecenia do Młodej Polski, Kraków 1966, s. 371. Zob. też [Reklama nut wydanych nakładem księgarni, składu nut i wypożyczalni S.A. Krzyżanowskiego], „Przewodnik Bibliograficzny”, R. 24: 1901, nr 8-9, s. 159 (reklama nut, m.in. czterech utworów W. Żeleńskiego i jednego dzieła J. Galla). Na przełomie 1904 i 1905 r. dwie publikacje nutowe wydane przez Krzyżanowskiego, w tym jedna z okładkami wykonanymi według projektu Stanisława Wyspiańskiego, były prezentowane na wystawie drukarskiej Krakowie, zob. Wystawa drukarska urzadzona staraniem Towarzystwa Polska Sztuka Stosowana w pałacyku hr. Czapskich w Krakowie. Od dnia 24 grudnia 1904 r. do 10 lutego 1905 r., Kraków 1905, s. 47, 106 (katalog wystawy).

${ }^{10}$ J. Reiss , Krakowscy pionierzy muzycznej kultury, „Ilustrowany Kurier Codzienny” 1936, nr 37, s. 2-3.

${ }^{11}$ W latach 1936-1937 w miesięczniku „Śpiewak” wydrukowano listy kompozytora Jana Galla do S.A. Krzyżanowskiego, zob. Listy Jana Galla do S. A. Krzyżanowskiego, wydał J. Reiss, „Śpiewak" 1936, nr 10, s. 122-125 [cz. 1], nr 11, s. 141-143 [cz. 2], nr 12, s. 158-159 [cz. 3], 1937, nr 1, s. 6-8 [cz. 4], nr 2, s. 20-21 [cz. 5], nr 3, s. 37-38 [cz. 6], nr 5, s. 67-69 [cz. 7], nr 6, s. 81-83 [cz. 8], nr 7/8, s. 92-94 [cz. 9], nr 9, s. 111-114 (dokończenie) [cz. 10].

${ }_{12}$ Zob. Bibliografia polskiego piśmiennictwa muzycznego, opracował K. Michałowski (Materiaty do bibliografii muzyki polskiej, t. III), Kraków 1955, s. 22-23, 26; Kronika, „Przewodnik Bibliograficzny”, R. 7: 1884, nr 12, s. 241-242; Kronika, „Przewodnik Bibliograficzny”, R. 10: 1887, nr 9, s. 178.

${ }^{13}$ Kronika, „Przewodnik Bibliograficzny”, R. 25: 1902, nr 8-9, s. 129; Kronika, „Przewodnik Bibliograficzny”, R. 16: 1893, nr 10, s. 190; Kronika, „Przewodnik Bibliograficzny”, R. 17: 1894, nr 10, s. 199; Kronika, ,Przewodnik Bibliograficzny”, R. 21: 1898, nr 10, s. 157; Kronika, „Przewodnik Bibliograficzny”, R. 24: 1901, nr 10, s. 157; Kronika, „Przewodnik Bibliograficzny”, R. 25 : 1902, nr 8-9, s. 129.

${ }^{14}$ Kronika, „Przewodnik Bibliograficzny”, R. 12: 1889, nr 12, s. 216; Kronika, „Przewodnik Bibliograficzny", R. 15: 1892, nr 10, s. 156.

15 Kronika, „Przewodnik Bibliograficzny”, R. 20: 1897, nr 2, s. 28; Kronika, „Przewodnik Bibliograficzny”, R. 21: 1898, nr 1, s. 17; Kronika, „Przewodnik Bibliograficzny”, R. 22: 1899, nr 1, s. 14; Kronika, „Przewodnik Bibliograficzny”, R. 23: 1900, nr 1, s. 17.

${ }^{16}$ Zob. Znaczniejsze księgarnie w Warszawie i ich komitenci, w: Kalendarz Księgarsko-Literacki na 1893 r., Warszawa 1892, s. 76. 
Do stałych klientów Krzyżanowskiego należał Ignacy Jan Paderewski, zawsze podczas wizyt w Krakowie odwiedzający jego sklep z książkami i nutami. Artysta miał sentyment do Stanisława Krzyżanowskiego z uwagi na młodzieńczy koncert z 1879 r. ${ }^{17}$

Publikacje wydawane przez Krzyżanowskiego były opatrywane znakiem firmowym, zawierającym inicjały (monogram) wydawcy - „S.A.K” - otoczone ozdobnym ornamentem ${ }^{18}$.

Właściciel monogramu działał w księgarskim ruchu zawodowym, od $1884 \mathrm{r}$. był zastępcą prezesa w Stowarzyszeniu Księgarzy Krakowskich, u boku prezesa Józefa Friedleina ${ }^{19}$.

Stanisław Krzyżanowski zmarł w 1922 r. w Krakowie. Spoczywa w grobie rodziny Krzyżanowskich na Cmentarzu Rakowickim ${ }^{20}$.

Syn, Marian Krzyżanowski, miał uzdolnienia artystyczne zarówno muzyczne, jak i plastyczne. Kształcił się w dziedzinie muzyki, a także studiował malarstwo i rysunek na Akademii Sztuk Pięknych w Krakowie, mając za mistrza profesora Floriana Cynka. Porzucił jednak plany w zakresie kariery artystycznej, rozpoczynając w 1903 r. wskutek decyzji ojca praktykę księgarską. Zdobył umiejętności zawodowe w rodzinnej księgarni, a także na stażach w warszawskiej firmie Gebethnera i Wolffa oraz u renomowanych księgarzy w Niemczech, Francji, Anglii i Austrii. Praca księgarza od początku dawała mu satysfakcję. Spośród klientów bardzo cenił pisarza Henryka Sienkiewicza. W 1908 r. przejął od ojca prowadzenie księgarni na Rynku Głównym ${ }^{21}$.

Nowy zarządzający kontynuował wydawanie nut. Ogłosił drukiem pieśn Czerwony sztandar ze słowami Bolesława Czerwieńskiego i Rotę Marii Konopnickiej z muzyką Feliksa Nowowiejskiego. Starał się edytować więcej publikacji książkowych niż wcześniej ojciec. Publikował utwory Władysława Orkana, Lucjana Rydla, Stanisława Wyspiańskiego i Stefana Żeromskiego. Wydawał książki dla dzieci. Ogłaszał drukiem przekłady zagranicznych dzieł literackich, dokonywane

17 M. Krzyżanowski, op. cit., s. 138-139.

18 S. La m, Polskie znaki księgarskie, Warszawa 1921, s. 16, 22 (na s. 22 - rysunek z sygnetu firmowego Krzyżanowskiego).

19 Wiadomości bieżace krajowe, „Gazeta Warszawska” 1883/4, nr 9, s. 1-2; Kronika, „Przewodnik Bibliograficzny”, R. 7: 1884, nr 2, s. 38. Zob. też: F. Piec zątkowski, Krzyżanowski Stanisław Andrzej..., s. 479.

${ }^{20}$ F. Pi e c zątk ow ski, Krzyżanowski Stanisław Andrzej..., s. 479; B. Łopuszański, op. cit., s. 618 .

${ }^{21}$ F. Pi e czątkowski, Krzyżanowski Marian (26 IV 1880 Kraków - 7 IX 1964 tamże) księgarz, nakładca i antykwariusz..., s. 479; idem, Krzyżanowski Marian (1880-1964), księgarz, wydawca i antykwariusz..., s. 612; idem, Marian Krzyżanowski (1880-1964), „Księgarz” 1965, nr 1, s. 66 (wspomnienie pośmiertne o Marianie Krzyżanowskim); A. Ruta, op. cit., s. 14-15; W. Ś 1 es iń s k i, Studenci, w: Materiaty do dziejów Akademii Sztuk Pięknych w Krakowie 1895-1939, [t. II], oprac. J.E. Dutkiewicz, J. Jeleniewska-Ślesińska, W. Ślesiński, Wrocław-Warszawa-Kraków 1969, s. 321; J. Okopień, op. cit., s. 38; M. Krzyżanow ski, op. cit., s. 135, 137, 160. 
m.in. przez Tadeusza Boya-Żeleńskiego, w tym pierwsze edycje jego prac translatorskich. Boy sam finansował wydania swych tłumaczeń. Krzyżanowski dawał wyraz dawnym pasjom, handlując polską i obcą literaturą o sztuce. Miał w ofercie także dzieła plastyczne: obrazy, ryciny, sztychy oraz reprodukcje. Po śmierci Stanisława Krzyżanowskiego w 1922 r. został właścicielem księgarni i wydawnictwa „S.A. Krzyżanowski”, pozostawiając dotychczasową nazwę ${ }^{22}$. Zgodnie z tradycją firmy sprzedawał bilety na koncerty odbywające się w Krakowie ${ }^{23}$.

Marian Krzyżanowski, analogicznie jak Stanisław Krzyżanowski, pełnił ważne funkcje w księgarskich organizacjach zawodowych. We wrześniu 1918 r. był jednym z organizatorów i uczestników I Zjazdu Księgarzy Polskich, mającego miejsce w Lublinie. Pod koniec lat trzydziestych, do 1939 r., piastował urząd prezesa w Kole Krakowskim Związku Księgarzy Polskich ${ }^{24}$.

Utrzymywał kontakt ze środowiskiem polskich plastyków, należąc od $1925 \mathrm{r}$. do stowarzyszenia krakowskich malarzy, jakim był cech Jednoróg, powstały w tymże roku. Wśród jego przyjaciół byli słynni artyści: malarze Julian Fałat i Włodzimierz Tetmajer, rzeźbiarz Xawery Dunikowski czy scenograf i malarz Karol Frycz ${ }^{25}$.

Jako wydawca ogłosił serię albumów Imago Poloniae, w tym przed samym wybuchem II wojny światowej dwie pozycje: Wawel i Matejko, których nakład został w znacznej części skonfiskowany przez niemieckiego okupanta. Niemcy zniszczyli także wszystkie egzemplarze albumu Kraków, w całości wydrukowanego, ale nieprzekazanego do obrotu księgarskiego ${ }^{26}$.

W okresie II wojny światowej ograniczył działalność handlową głównie do antykwarycznej. Od 1940 r. prowadził księgarnię i wydawnictwo na placu Wolnica

${ }^{22}$ F. Pieczątkowski, Krzyżanowski Marian (26 IV 1880 Kraków - 7 IX 1964 tamże) księgarz, nakładca i antykwariusz..., s. 479-480; idem, Krzyżanowski Marian (1880-1964), ksiegarz, wydawca $i$ antykwariusz..., s. 612; idem, Marian Krzyżanowski (1880-1964)..., s. 66-67; A. R u ta, op. cit., s. 16, 38-54; J. Okopień, op. cit., s. 38-39; J. Zieliński, op. cit., s. 13; A. Słapa, Doktor Tyssot albo wspomnienie o Boyu wydawcy, w: Kopiec wspomnień..., s. 424-426; L. F i s z e r, Wspomnienia starego księgarza, Warszawa 1959, s. 22.

${ }^{23}$ Zob. np. „Naprzód” 1922, nr 230, s. 6 (numer datowany: Kraków, piątek 13 października 1922) (notatka bez tytułu, stanowiąca zapowiedź krakowskiego koncertu śpiewaka basa Kazimierza Skoczylasa).

${ }^{24}$ F. Pi ec zątkowski, Krzyżanowski Marian (26 IV 1880 Kraków - 7 IX 1964 tamże) księgarz, nakładca i antykwariusz..., s. 480; idem, Krzyżanowski Marian (1880-1964), ksiegarz, wydawca $i$ antykwariusz..., s. 613; I Zjazd Księgarzy Polskich. Sprawozdanie komitetu organizacyjnego, „Przegląd Księgarski” 1818, nr 1, s. 1-23; L. F i s ze r, op. cit., s. 197-205; J. O k o pi eń, op. cit., s. 39; J. Zieliński, op. cit., s. 13.

${ }^{25}$ F. Pieczątkowski, Krzyżanowski Marian (1880-1964), ksiegarz, wydawca i antykwariusz..., s. 613; A. Ruta, op. cit., s. 20; T. D o browols k i, Nowoczesne malarstwo polskie, t. III, Wrocław-Warszawa-Kraków 1964, s. 232-247; M. Kr zy ża n ow s ki, op. cit., s. 145.

${ }^{26}$ F. Pi e c zątkows ki, Krzyżanowski Marian (26 IV 1880 Kraków - 7 IX 1964 tamże) księgarz, nakładca i antykwariusz..., s. 480; idem, Krzyżanowski Marian (1880-1964), księgarz, wydawca $i$ antykwariusz..., s. 613; A. Ruta, op. cit., s. 16. 
na Kazimierzu, gdzie zostały przeniesione na żądanie hitlerowców. Krzyżanowski w miarę możliwości wydawał wtedy książki, przede wszystkim literaturę dziecięco-młodzieżową ${ }^{27}$.

Po zakończeniu okupacji hitlerowskiej powrócił jeszcze w 1945 r. do siedziby na Rynku Głównym. Dopóki było to możliwe, kontynuował działalność księgarską i wydawniczą. Ogłaszał drukiem głównie publikacje książkowe dla odbiorcy dziecięcego. Kiedy w 1950 r. powstał państwowy, scentralizowany Dom Książki, musiał ograniczyć się do prowadzenia antykwariatu, w którym kupował i sprzedawał książki oraz materiały nutowe. Umieścił swoją firmę na piętrze budynku przy ul. Szczepańskiej 5. Od 1960 r. miał antykwariat w nowym miejscu, w lokalu po sklepie na placu Szczepańskim. Prowadził go do swej śmierci, która nastąpiła we wrześniu 1964 r. Został pochowany na Cmentarzu Rakowickim, w jednym grobie z bliskimi ${ }^{28}$.

Księgarz i wydawca Feliks Pieczątkowski w zamieszczonym w czasopiśmie „Księgarz” wspomnieniu pośmiertnym napisał:

Po kilkudniowej zaledwie chorobie zmarł 7 września 1964 r. w Krakowie w wieku 84 lat senior księgarstwa polskiego Marian Krzyżanowski - wybitny księgarz, wydawca i antykwariusz krakowski. Śmierć zabrała go niemal od kontuaru antykwariatu, który ostatnio prowadzi129.

Autor wspomnienia zamieszczonego w krakowskim „Dzienniku Polskim”, Ryszard Kosiński, utożsamił zmarłego z jego miastem, stwierdzając, iż „Krzyżanowski - to przede wszystkim Kraków, to element jego całości i współtowarzysz

${ }^{27}$ F. Piec ząt kow ski, Krzyżanowski Marian (26 IV 1880 Kraków - 7 IX 1964 tamże) księgarz, nakładca i antykwariusz..., s. 480; idem, Krzyżanowski Marian (1880-1964), księgarz, wydawca $i$ antykwariusz..., s. 613; A. Ruta, op. cit., s. 16-17, 55-66; idem, Marian Krzyżanowski (1880-1964)..., s. 67; J. Okopień, op. cit., s. 39; J. Zieliński, op. cit., s. 13; S. Pazyra, Z dziejów książki polskiej w czasie drugiej wojny światowej, Warszawa 1970, s. 236.

${ }^{28}$ F. P i c ząt kow ski, Krzyżanowski Marian (26 IV 1880 Kraków - 7 IX 1964 tamże) księgarz, nakładca i antykwariusz..., s. 480; idem, Krzyżanowski Marian (1880-1964), ksieggarz, wydawca i antykwariusz..., s. 613; idem, Marian Krzyżanowski (1880-1964)..., s. 67; A. Rut a, op. cit., s. 17-21, 67-72; J. Zi elińsk i, op. cit., s. 13. Księgarz Ludwik Fiszer tak pisał pod koniec lat pięćdziesiątych o okresie, gdy Krzyżanowski prowadził firmę na Szczepańskiej: „Firma Krzyżanowskiego istnieje po dziś dzień na ul. Szczepańskiej nr 5, gdzie na piętrze ostatni jej właściciel, sędziwy Marian Krzyżanowski, prowadzi niewielki antykwariat. Marian Krzyżanowski jest jeżeli nie najstarszym, to jednym z najstarszych księgarzy w Polsce. Pracuje w księgarstwie prawie 60 lat”, L. Fiszer, op.cit, s. 161. Promocji antykwariatu M. Krzyżanowskiego, działającego w późniejszej siedzibie, dobrze służył artykuł Kazimierza Dziewanowskiego zawierający elementy reportażu z wizyty u antykwariusza przy placu Szczepańskim, wydrukowany w periodyku „Świat” ponad dwa i pół roku przed śmiercią księgarza, zob. K. Dzi ew a now ski, Krakowskim targiem..., zdjęcia W. Prażuch, „Świat” 1962, nr 2, s. [9]-[10] (numer datowany: 14 stycznia 1962 r.).

${ }^{29}$ F. Pieczątkowski, Marian Krzyżanowski (1880-1964)..., s. 66. 


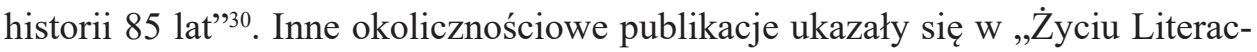
kim”31 i „Tygodniku Powszechnym”32.

Brat Mariana Krzyżanowskiego, Adam Krzyżanowski, zrobił karierę naukową jako profesor ekonomii na Uniwersytecie Jagiellońskim ${ }^{33}$.

Po przypomnieniu działalności księgarzy Krzyżanowskich w Krakowie należy omówić dokumenty życia muzycznego i teatralnego zebrane przez Mariana Krzyżanowskiego. Przeanalizowane niżej druki ulotne mają rozmiary 31,5 x $18,5 \mathrm{~cm}$ i mniejsze ${ }^{34}$.

Dokumentację części życia muzycznego Krakowa stanowią afisze z zapowiedziami koncertów odbywających się w Hotelu Saskim, organizowanych przez biuro koncertowe Stanisława A. Krzyżanowskiego. W większości nie dotyczą one występów artystów, którzy weszli do historii muzyki, ale ukazują krakowskiego księgarza jako animatora i popularyzatora kultury. Koncerty mniej znanych, w tym początkujących, wykonawców służą bowiem promocji muzyków, dając im szansę na początek albo rozwój kariery. Razem z występami sław składają się na całokształt życia muzycznego danego kraju, regionu czy miasta.

$\mathrm{Na}$ drukach informowano o dacie, godzinie i miejscu wydarzenia oraz wykonawcach i programie muzycznym. Podawano wiadomość o cenie biletów i miejscu, gdzie można je kupić.

Na środę 12 listopada 1884 r., na godz. 19.30 („,wpół do 8-mej wieczór”) zapowiadano koncert dwóch artystek - Wandy Bulewskiej, grającej na fortepianie i skrzypaczki Jadwigi Bulewskiej, określonej jako wiolinistka. W programie znalazły się utwory polskich kompozytorów romantycznych: Fryderyka Chopina i Henryka Wieniawskiego. Zgodnie z informacją z afisza wykonawczynie miały zagrać w duecie mazurka Wieniawskiego, a Wanda Bulewska solo impromptu i walca Chopina. Utwory obcych kompozytorów wybrane na koncert to andante i rondo z siódmego koncertu skrzypcowego belgijskiego skrzypka Charles'a Augusta de Bériota (1802-1870), ballada i polonez koncertowy innego belgijskiego twórcy, Henriego Vieuxtempsa (1820-1881), Sonata D-dur Ludwiga van Beethovena, a także Medytacja Charles'a Gounoda, oparta na utworze Jana Sebastiana Bacha, czyli najprawdopodobniej Ave Maria Gounoda z 1859 r., stanowiąca

${ }^{30}$ R. Ko sińs ki, Epitafium dla Krzyżanowskiego, „Dziennik Polski” 1964, nr 217, s. 3 (numer datowany: Kraków, sobota, 3 IX 1964).

${ }^{31}$ Zob. S. D zi ki, Zmarł Marian Krzyżanowski, „Życie Literackie” 1964, nr 38, s. 15 (Kraków, 20 września 1964 r.).

32 Zob. J. S u suł, Jeden z ostatnich, ,Tygodnik Powszechny” 1964, nr 41, s. 4 (Kraków, 11 października 1964).

${ }_{33}$ B. Łopuszański, op. cit., s. 618; Z. Landau, Krzyżanowski Adam Alojzy (1873-1963), w: PSB, t. XV..., s. 588-594.

${ }^{34}$ Zob. Katalog rękopisów Biblioteki Polskiej Akademii Nauk w Krakowie. Sygnatury $3607-4003 \ldots$, s. 52. 
nawiązanie do pierwszego preludium C-dur z Das Wohltemperierte Klavier Bacha. Dzieła Beriota, Vieuxtempsa i Bacha Gounoda pianistka i skrzypaczka miały wykonać razem. W przypadku Ave Maria Gounoda partia skrzypcowa stanowiła aranżację części utworu przeznaczonej na głos śpiewaczki, a gra na fortepianie była akompaniamentem. Sonatę Beethovena zapowiadano, zgodnie z oryginałem, w wykonaniu fortepianowym bez towarzyszenia skrzypiec. Ceny biletów były następujące: 1 złoty reński za sam wstęp, 3 złote reńskie za miejsca w pierwszych rzędach, 2 złote reńskie za bilety w następnych rzędach, 1 złoty reński i 20 centów za miejsca na galerii. Zachęcano publiczność do przybycia, informując: „Biletów można nabyć w Księgarni S.A. Krzyżanowskiego"35.

O dziewięć lat młodszy jest afisz stanowiący zapowiedź koncertu pianistki i kompozytorki Natalii Janothównej (1856-1932) w Hotelu Saskim w dniu 5 maja 1893 r. o godz. 19.30. Dochód z niego przeznaczano na budowę gmachu krakowskiego Towarzystwa Muzycznego. Natalia Janotha wykonała solo Sonatę cis-moll Beethovena i Carnaval Roberta Schumanna. Zagrała też m.in. Piosenkę litewska Fryderyka Chopina w opracowaniu Giovanniego Sgambatiego (znana pieśń, zaczynająca się od słów Rano, raniutko) oraz utwór własnej kompozycji: fortepianowy Gavot impériale, powstały około 1890 r. Inne dzieło Janothównej, którego prezentację zapowiadano na 5 maja, to Ave Maria na głosy mieszane, dedykowane papieżowi Leonowi XIII (1810-1903, papież w latach 1878-1903), w wykonaniu mieszanego kwartetu wokalnego działającego przy Towarzystwie Muzycznym w Krakowie. W programie znalazły się także Pieśni ludowe na chór męski polskiego kompozytora Jana Galla. Bilety kosztowały 3 złote reńskie (pierwsze miejsca), 1 złoty reński 50 centów (drugie miejsca), 1 złoty reński (miejsca na balkonie), 50 centów za samo wejście do sali koncertowej. Sprzedawano je w księgarni S.A. Krzyżanowski ${ }^{36}$.

Dzień 3 kwietnia 1898 r. był datą koncertu muzyki religijnej, na jaki zapraszano publiczność do sali w Hotelu Saskim. Wpływy z biletów przeznaczano na Towarzystwo Świętego Wojciecha. Występ zaczynał się o 19.30. Przed słuchaczami zaprezentowały się m.in. chór towarzystwa Lutnia i orkiestra. Funkcję dyrygenta pełnił Jan Nepomucen Hock (ok. 1845 - po 1914). Do programu wybrano takie utwory, jak orkiestrowe preludium z misterium Ewa Jules'a Masseneta, Ave Maria Franza Schuberta ('śpiew solo), Legendy Antonína Dvoř́ka (wykonanie na fortepianie), Religioso Pietra Locatellego (1695-1764) w skrzypcowym wykonaniu solowym, U stóp krzyża Gabriela Fauré, Hymn Świętego Wojciecha - Boga Rodzico z X w., a także Improperia, skomponowane przez szesnastowiecznego artystę Giovanniego Pierluigiego da Palestrina. Chór Lutni zaśpiewał Ave Verum Wolfganga Amadeusza Mozarta z XVIII w. Wykonał też Hymn za Ojczyznę Charles'a Gounoda z akompaniamentem orkiestrowym. Bilety w cenie 3 złote reńskie

35 BN PAU i PAN w Krakowie, rkps 3736, k. 1.

36 Ibidem, k. 2-3 (dwa egzemplarze tego samego afisza). 
za miejsca w pierwszym rzędzie, 2 złote reńskie za miejsca w dalszych rzędach oraz 1 złoty reński za wstęp do sali względnie na galerię sprzedawano w tej samej księgarni, co w przypadku wydarzeń muzycznych omówionych wyżej ${ }^{37}$.

Firma Krzyżanowskich prowadziła również sprzedaż biletów na koncerty odbywające się w innych miejscach Krakowa niż Hotel Saski. Dowód to afisz z informacją o występie pianistki Heleny Lechowicz-Hochedlinger i śpiewaka barytona Witolda Szaniawskiego w Towarzystwie Muzycznym 25 lutego $1891 \mathrm{r}$. o godz. 19.30. Witold Szaniawski prowadził działalność artystyczną od 1880 r., a zmarł w 1920 r. W koncercie wziął udział także kompozytor Władysław Żeleński. Na bogaty program wieczoru złożyły się utwory grane solo na fortepianie lub wykonywane przez śpiewaka z akompaniamentem fortepianu czy wiolonczeli, których twórcami byli: Johannes Brahms, włoski muzyk Stanislao Gastaldone (1861-1939), Fryderyk Chopin, Charles Gounod, Anton Rubinstein, Gabriel Fauré, Stanisław Moniuszko, Władysław Żeleński i Ferenc Liszt. Cena biletu wynosiła 2 złote reńskie za krzesło i 50 centów za wstęp. Można go było nabyć nie tylko u Krzyżanowskiego - członkom Towarzystwa Muzycznego oferowano zniżkową opłatę za bilety sprzedawane w kancelarii towarzystwa ${ }^{38}$.

Wszystkie afisze, których treść omówiono, mają podobną postać graficzną. Informacje wydrukowano czarną farbą na jasnym tle, w prostokątnym obramowaniu. Na afiszu koncertu Bulewskich z 1884 r. znajdują się tylko proste litery, a obramowania nie uzupełniono prawie żadnymi ozdobami. Funkcję ozdobną pełnią jedynie skromne wzory geometryczne, umieszczone symetrycznie po czterech stronach obramowania tekstu ${ }^{39}$. W przypadku ogłoszenia o występie Janothównej (1893) nadano ramkom dekoracyjny wygląd stylowej ramy obrazu. Mocno zróżnicowano barwę liter, operując czernią i bielą, a także ich formaty i krój, szczególnie w nagłówku ${ }^{40}$. Afisz z wiadomością o koncercie Heleny Lechowicz-Hochedlinger oraz Witolda Szaniawskiego z $1891 \mathrm{r}$. jest mniej efektowny graficznie od tego z 1893, ale bardziej reprezentacyjny od afisza z 1884 r. Ma ramki z geometrycznym wzorem, a liternictwo zastosowane w nagłówku cechuje się różnymi formatami i krojami ${ }^{41}$. Na temat grafiki afiszowego ogłoszenia o koncercie muzyki religijnej z 1898 r. można stwierdzić to samo, co o druku młodszym o siedem lat ${ }^{42}$.

Jeden spośród druków zgromadzonych przez Mariana Krzyżanowskiego dotyczy wydarzenia muzycznego mającego miejsce w Warszawie. Jest to zaproszenie na koncert Warszawskiego Towarzystwa Śpiewaczego Lutnia, organizowany we wtorek 17 października 1899 r. w archikatedrze warszawskiej, czyli w kościele Świętego Jana w Warszawie, na okoliczność pięćdziesiątej rocznicy śmierci

${ }^{37}$ Ibidem, k. 9.

${ }^{38}$ Ibidem, k. 4.

39 Ibidem, k. 1.

${ }^{40}$ Ibidem, k. 2-3 (dwa egzemplarze tego samego afisza).

${ }^{41}$ Ibidem, k. 4.

${ }^{42}$ Ibidem, k. 9. 
Fryderyka Chopina. Nie podano godziny rozpoczęcia koncertu Lutni, ale informowano o nabożeństwie żałobnym ,za duszę Mistrza”, zapowiadanym na godz. 11.00 , z czego można wnioskować, iż program koncertowy wykonano bezpośrednio po nim. Nie wymieniono też utworów przygotowywanych do chóralnego wykonania. Na zaproszeniu nie ma imienia i nazwiska zapraszanej osoby ani miejsca na jego wpisanie ${ }^{43}$, a więc musiało być rozprowadzane jako druk ulotny $\mathrm{z}$ informacją o koncercie dla różnych czytających je osób.

Zaproszenie to skromny czarno-biały druk. Czcionki mają formę kursywy, zaś nazwę towarzystwa - Lutnia - oraz imię i nazwisko Fryderyka Chopina wydrukowano mocniejszą czarną farbą niż pozostałe wyrazy składające się na tekst informacyjny. Na verso zamieszczono ilustrację - portret głowy Fryderyka Chopina z profilu, zaś w tle wizerunek dworku symbolizującego dworek w Żelazowej Woli. Obok, po prawej, umieszczono błędną datę urodzin kompozytora (2 marca 1809, zamiast 1 marca 1810) i poprawną datę jego śmierci (17 października 1849). W prawym dolnym rogu umieszczono informację o drukarni: „Warszawa. Druk Towarzystwa S. Orgelbranda synów"44.

Kilka dokumentów z kolekcji Krzyżanowskiego zawiera również wiadomości na temat życia teatralnego Krakowa i Warszawy w latach 1908-1955. Kolekcjoner gromadził je, będąc miłośnikiem teatru. Pisarz i malarz Antoni Waśkowski wspominał na jego temat, że na początku XIX w. „,nie opuścił ani jednej premiery" w krakowskim Teatrze im. Słowackiego ${ }^{45}$. Krzyżanowski dobrze zapamiętał wesele Lucjana Rydla i Jadwigi Mikołajczykówny z listopada 1900 r. oraz premierę Wesela Wyspiańskiego, późniejszą o kilka miesięcy, czemu dał wyraz we Wspomnieniach księgarza, opublikowanych w 1964 r. w tomie zbiorowym Kopiec wspomnieñ ${ }^{46}$. Do umiejętności księgarza-teatromana należało imitowanie głosów artystów dramatycznych, czym chętnie zabawiał przyjaciól, prezentując z pamięci fragmenty aktorskich kreacji. Miał przekazywać aktorkom w każdą sobotę kosze z kwiatami ${ }^{47}$.

Najstarszy druk o tematyce teatralnej, sprzedany przez Krzyżanowskiego do biblioteki, pochodzi z 1908 r. i jest trzystronicową ulotką zawierającą na pierwszej stronie informację o „wielkim koncercie Michała Tarasiewicza na dochód sprowadzenia zwłok Juliusza Słowackiego do kraju". Zapraszano widzów na 8 marca 1908 r. do starego teatru w Krakowie. Jako organizatora imprezy wymieniano Akademicki Komitet dla Sprowadzenia Zwłok Juliusza Słowackiego do Kraju. U góry pierwszej strony ulotki, nad nagłówkiem, znalazł się portret poety

${ }^{43}$ BN PAU i PAN w Krakowie, rkps 3736, k. 10.

${ }^{44}$ Ibidem, k. 10-10v.

${ }^{45}$ A. Waśkowski, Znajomi z tamtych czasów (literaci, malarze, aktorzy) (1892-1939), Kraków 1960, s. 151.

${ }^{46}$ M. Krzyżanowski, op. cit., s. 160-164.

${ }^{47}$ A. Waśkowski,op. cit., s. 151. Zob. też J. Okopień, op. cit., s. 38. 
en face (kopia znanego wizerunku, na którym nosi on kołnierz wyłożony na ubranie). Na odwrocie zaproszenia wydrukowano znak firmowy i nazwę oficyny poligraficznej, z której wyszło, czyli drukarni Antoniego Koziańskiego w Krakowie ${ }^{48}$.

Koncert z 8 marca 1908 r. miał charakter występu aktorskiego, głównie recytatorskiego, ponieważ Michał Tarasiewicz (1871-1923) był aktorem i reżyserem teatralnym. Natomiast do sprowadzenia szczątków wieszcza do Polski i złożenia ich w katedrze wawelskiej doszło znacznie później, w 1927 r.

Interesujący druk ze zbioru Krzyżanowskiego pochodzi z okresu I wojny światowej. Jest to czterostronicowy program XIV Wieczoru Klasycznego, zapowiadanego na poniedziałek 13 grudnia 1915 r., który miał być prezentowany na scenie Teatru Miejskiego im. Juliusza Słowackiego w Krakowie. Organizatorem wieczorów było Akademickie Koło Artystyczne Miłośników Dramatu Klasycznego. Wpływy z biletów przeznaczano na działalność Komitetu Książęco-Biskupiego dla Dotkniętych Wojną. W programie spektaklu z 13 grudnia znalazły się trzy dramaty antyczne: dwie sceny z Rozmów umarlych Lukiana, Sen albo kogut tego samego autora oraz Alkestis Eurypidesa. Lukiana grano w przekładzie filologa klasycznego profesora Michała Boguckiego (1860-1935). „Reżyserem filologicznym" trzech inscenizacji był profesor Bogucki, a reżyserią właściwą zajął się „reżyser artystyczny” wieczoru - aktor Zygmunt Noskowski (1880-1952) (inna osoba niż kompozytor o tym samym imieniu i nazwisku, który żył w latach 1846-1909). Na druku podano informacje o oprawie muzycznej sztuk Lukiana i obsadzie wszystkich trzech realizacji. W inscenizacjach Rozmów umarłych i Snu albo koguta można było wysłuchać starogreckiego Hymnu do Apollona i bizantyjskiego hymnu ostatniego cesarza Bizancjum Konstantego XI Paleologa. Śpiewano też hymn do Afrodyty z tekstem Safony, skomponowany przez Jana Tomasza Sekalleridesa. Alkestis Eurypidesa grano w poetyckim tłumaczeniu pióra Bolesława Karpińskiego (1879-1939). Gwiazdami wieczoru byli Zygmunt Noskowski w roli Charona w Rozmowach umartych i legendarna artystka dramatyczna Irena Solska jako tytułowa Alkestis w sztuce Eurypidesa. Pod spisami obsad kolejnych sztuk informowano o fikcyjnych miejscach akcji. Na koniec druku trafiły omówienia treści trzech dramatów, z nagłówkiem Sinopsis ${ }^{49}$.

Program ma efektowną oprawę graficzną, choć jest czarno-biały. Są to dwie dwustronnie zadrukowane karty. W środkowej części strony pierwszej znalazł się wizerunek dwóch postaci w antycznych strojach, przyjmujących teatralne pozy, jedna trzyma rękę na ramieniu drugiej. Nazwę organizatora, słowa XIV Wieczór Klasyczny, a także informację o dacie i miejscu spektaklu wydrukowano dużymi literami ${ }^{50}$. Nad spisem obsad sztuk Lukiana znalazły się portrety M. Boguckiego i Z. Noskowskiego w okrągłych obramowaniach. Identyczny kształt mają

\footnotetext{
${ }^{48}$ BN PAU i PAN w Krakowie, rkps 3736, k. 7-7v.

${ }^{49}$ Ibidem, k. 13-14v.

${ }^{50}$ Ibidem, k. 13.
} 
podobizny I. Solskiej i B. Karpińskiego, zamieszczone nad obsadą Alkestis. Pod portretami podano, kogo one przedstawiają. Na dole strony trzeciej informowano na temat podobizn: „Klisze wykonane w zakładzie art.-fotograficznym Kuczyńskiego" ${ }^{1}$. Chodziło o firmę fotograficzną, działającą w Krakowie od 1907 r., prowadzoną z początku wspólnie przez Józefa Kuczyńskiego i Józefa Gürtlera, a od 1912 r. przez Kuczyńskiego samodzielnie. Na dole ostatniej, czwartej, strony podano pod rysunkiem przedstawiającym groteskową maskę teatralną wiadomość o oficynie poligraficznej, w której wydrukowano program: „Drukarnia Związkowa w Krakowie, Mikołajska 13" "52. Wymieniona firma drukarska istnieje w Krakowie od 1876 r., stale pod tym samym adresem.

Kolejny krakowski druk teatralny jest zaproszeniem na główną uroczystość obchodów sześćdziesięciolecia Teatru im. Juliusza Słowackiego w Krakowie 29 stycznia 1955 r., godz. 19.15, stanowiącym ważny dokument źródłowy dla badaczy dziejów tej sceny. Nie ma na nim imienia i nazwiska zapraszanej osoby ani też miejsca na ich wpisanie. Zaproszenie to ośmiostronicowa książeczka. Z jej treści wynika, iż najważniejsza impreza jubileuszowa miała miejsce po spektaklu Fantazego Słowackiego. Była częścią kilkudniowych obchodów, odbywających się pod nazwą „festiwal jubileuszowy”. Na kilku stronach wymieniano skład komitetu jubileuszowego z ministrem kultury i sztuki Włodzimierzem Sokorskim na czele. Ostatnia natomiast zawiera wyliczenie członków komitetu wykonawczego, kierowanego przez Karola Frycza jako przewodniczącego honorowego oraz przez aktora i reżysera teatralnego Wacława Nowakowskiego (1888-1962). Przedostatnia strona zawiera wykaz sztuk granych w dniach obchodów. Do repertuaru trafiły wówczas, oprócz Fantazego, Zemsta i Śluby panieńskie Aleksandra Fredry, Polacy nie gęsi Ludwika Hieronima Morstina, a także dramat autora zagranicznego: Kaukaskie kredowe koło Bertolta Brechta ${ }^{53}$.

W programie znalazł się tylko jeden znaczący element graficzny - rysunkowy motyw w stylu secesyjnym na górze pierwszej, tytułowej, strony, otaczający nazwę instytucji świętującej jubileusz: „Państwowy Teatr im. J. Słowackiego w Krakowie". Pod nazwą podano imię i nazwisko ówczesnego kierownika artystycznego teatru - Henryka Szletyńskiego. Niżej znalazła się nazwa jubileuszu: „Jubileusz 60-lecia Teatru im. J. Słowackiego w Krakowie”, a na samym dole data obchodów: ,29.I. - 2.II.1955 r." ${ }^{\text {. }}$.

Inny druk jubileuszowy to imienne zaproszenie dla Mariana Krzyżanowskiego na jubileusz aktorki Antoniny Klońskiej (1883-1969), na 19 listopada 1955 r., godz. 20.00, do Teatru Poezji w Krakowie, firmowany przez tamtejszy Teatr Stary. Świętowano pięćdziesięciolecie pracy aktorskiej artystki ${ }^{55}$. Zaproszenie ma for-

\footnotetext{
${ }^{51}$ BN PAU i PAN w Krakowie, rkps 3736, k. 13v-14.

52 Ibidem, k. 14v.

${ }^{53}$ Ibidem, k. 19-22v.

${ }^{54}$ Ibidem, k. 19.

${ }^{55}$ Ibidem, k. 15-18.
} 
mę małej, wąskiej, siedmiostronicowej książeczki. Na stronie tytułowej (strona pierwsza) wydrukowano dane o jubileuszu oraz jego dacie i organizatorze. Strony drugą, czwartą, piątą, szóstą i siódmą przeznaczono na wymienienie licznych członków komitetu jubileuszowego. Na stronie trzeciej zapraszano Krzyżanowskiego na jubileuszowe przedstawienie Domu kobiet Zofii Nałkowskiej w reżyserii Haliny Gall. Klońska grała Celinę Bełską. Imię i nazwisko zapraszanego księgarza dopisano na druku ręcznie. Jedyna ilustracja to mały rysunek na stronie tytułowej, przedstawiający kosz kwiatów ${ }^{56}$.

Z Warszawy natomiast pochodzi program benefisu aktora i śpiewaka Juliana Krawczyńskiego, prowadzącego działalność artystyczną od 1907 do 1921 r. Program wydrukowano na papierze gazetowym. Jest drukiem dwujęzycznym - polsko-rosyjskim. Wynika z niego, iż benefis Krawczyńskiego miał miejsce w 1913 r. w Teatrze Dynasy w Warszawie. Nazwa teatru pochodziła stąd, iż znajdował się w Warszawie na ulicy Dynasy. W programie nie przywołano daty dziennej spektaklu, informując jedynie, iż „dziś” zostanie zagrane benefisowe przedstawienie jednoaktowej operetki Thomasa Koschata Skarb za kominem z akcją toczącą się w Tyrolu, m.in. z Krawczyńskim w roli Seppiego. W ramach tego samego wieczoru proponowano obejrzenie muzycznej sztuki ludowej Swaty ze śpiewami i tańcami skomponowanymi przez E. Dominiego, z polskim tańcem - mazurem. W obsadzie Swatów nie było Krawczyńskiego. Na koniec spektaklu zaplanowano program kabaretowy - Igraszki kabaretowe w wykonaniu Józefa Zejdowskiego, występującego w Teatrze Dynasy gościnnie. O przybliżonej dacie benefisu Krawczyńskiego świadczy informacja z drugiej strony, że program dotyczy sezonu Teatru Dynasy, datowanego na 1913 r. Podano imię i nazwisko dyrektora sceny, którym był Janusz Drac ${ }^{57}$.

Większość druku zajmują polsko-rosyjskie reklamy firm handlowych i usługowych, w tym zakładów gastronomicznych i konkretnych produktów, czasem ilustrowane ${ }^{58}$. Reklamy mogą zostać potraktowane jako materiał źródłowy dla badaczy dziejów życia gospodarczego Warszawy, zainteresowanych okresem bezpośrednio przed wybuchem I wojny światowej.

Druki, zgromadzone przez Mariana Krzyżanowskiego, dostępne w Bibliotece Naukowej PAU i PAN w Krakowie, dotyczące życia muzycznego i teatralnego Krakowa oraz Warszawy w XIX i XX wieku, stanowią nieduży, ale interesujący zbiór, wartościowy dla historyków kultury. Badając konkretne tematy, np. działalność biura koncertowego firmy księgarskiej S.A. Krzyżanowski czy jubileusz sześćdziesięciolecia Teatru Słowackiego, można je zestawiać z innymi materiałami źródłowymi oraz z efektami kwerend prasowych, a także z wiadomościami z opracowań naukowych i popularyzatorskich.

\footnotetext{
56 Ibidem, k. 15.

57 Ibidem, k. 11-12.

58 Ibidem.
} 
ADRIAN ULJASZ

\section{SOCIAL LIFE DOCUMENTS}

FROM THE COLLECTION OF THE BOOKSELLER MARIAN KRZYŻANOWSKI

AS A SOURCE OF RESEARCH ON THE MUSICAL AND THEATRICAL LIFE

OF CRACOW AND WARSAW IN THE $19^{\mathrm{TH}}$ AND $20^{\mathrm{TH}}$ CENTURY

Keywords: Marian Krzyżanowski (1880-1964), musical life, theatre, Cracow, Warsaw, XIX c., XX c., history

\section{Summary}

Programs and posters of theatre performances and concerts, as well as similar prints, serve as a valuable source of research on the tradition of the theatrical and musical life of particular cities. The Scientific Library of the PAAS and the PAS in Cracow contains materials of this kind referring to cultural events in Cracow and Warsaw, which were collected by the Cracow bookseller, antiquarian and publisher Marian Krzyżanowski, a son of the Cracow bookseller and publisher Stanisław Andrzej Krzyżanowski. These are posters from classical music concerts, theatrical programs and invitations. The documents were prepared in the years 1884-1955. A large part of them is the documentation of the activity of the concert office run by Stanisław Krzyżanowski beside the bookshop from 1870 .

These prints are analysed in the paper. The overview of social life documents was preceded by information about Stanisław Andrzej Krzyżanowski and his son Marian and their activity in such fields as the animation of musical culture.

\section{АДРИАН УЛЬЯШ (ADRIAN ULJASZ)}

ДОКУМЕНТЫ, ПРЕДСТАВЛЯЮЩИЕ ОБЩЕСТВЕННУЮ ЖИЗНЬ, ИЗ КОЛЛЕКЦИИ КНИГОТОРГОВЦА МАРЬЯНА КРЖИЖАНОВСКОГО КАК ИСТОЧНИК ДЛЯ ИССЛЕДОВАНИЙ НАД МУЗЫКАЛЬНОЙ И ТЕАТРАЛЬНОЙ ЖИЗНЬЮ КРАКОВА И ВАРШАВЫ В ХІХ И ХХ ВЕКАХ

Ключевые слова: Мариан Кшижановский (1880-1964); музыкальная жизнь, театр, Краков, Варшава, XIX в., XX в., история

\section{Резюме}

Ценным источником в исследованиях традиции театральный и музыкальной жизни конкретных городов являются программы и афиши с театральными постановками и концертами, а также другие подобного рода печатные издания. В собраниях Научной библиотеки Польской академии знаний (PAU) и Польской академии наук (PAN) в Кракове находятся материалы подобного рода, относящиеся к культурным мероприятиям, которые проходили в Кракове и Варшаве, и собранные краковским книготорговцем, антикваром и издателем Марьяном Кржижановским, сыном книготорговца, издателя и инвестора из Кракова, Станислава Анджея Кржижановского. Это 
афиши концертов классической музыки, театральные программы и приглашения. Временные границы создания этих документов - это 1884-1955 гг. Большая часть материалов - это документация работы концертного бюро, которое действовало под началом Станислава Кржижановского в его книжном магазине с 1870 года.

В статье были проанализированы эти печатные издания. Перед обсуждением документов, посвященных общественной жизни, автор представил информацию о Станиславе Анджее и Марьяне Кржижановских, а также о их деятельности, в том числе в области продвижения музыкальной культуры. 